\title{
KONTINYUITAS PENDAMPINGAN PELAKU EKONOMI KREATIF BERBASIS SINGKONG SELAMA TERJADI WABAH COVID-19 GUNA MENJAGA EKSISTENSI USAHANYA MELALUI STIMULAN DANA USAHA
}

\author{
Masyhuri Machfudz* \\ Program Studi Agribisnis, Fakultas Pertanian, Universitas Islam Malang \\ *Email Korespondensi: masyhuri.machfudz@unisma.ac.id
}

Submitted : 1 Desember 2020; Revision : 15 Desember 2021; Accepted : 15 Februari 2021

\begin{abstract}
ABSTRAK
Tujuan pendidikan dan pendampingan (P2) ini untuk melakukan pemantauan pada kelompok ekonomi kretif saat wabah covid-19. Kelompok sasaran pada pengabdian ini adalah pelaku ekonomi kreatif (singkong) khususnya saat terjadi masa diberlakukan PSBB (pembatasan sosial berskala besar 2020) dengan metode yang dilakukan melalui pendampingan secara terus menerus. Hasil pengabdian menjukkan bahwa (i) keberhasilan aktivitas hulu, yaitu usahatani singkong yang dilakukan tetap berjalan sebagaimana kondisi sebelum wabah covid-19, dampak stimulan dana bergulir tidak merasa membebaninya (nyaman); (ii) kenyamanan yang terbangun diindikasi oleh kesepakatan (agreement) pada kelompok sasaran; dan (iii) pengembalian 'dana stimulant bergulir' dilakukan melalui berbagai macam variasi sesuai dengan kemampuannya. Rekomendasi yang dapat disampaikan pada program ini adalah program tetap dilanjutkan dan/atau dikembangkan karena dampak sosialnya berupa kenyamanan yang muncul pada saat sedang atau telah program berjalan dampak ekonomi keberlangsungan (sustainable) dukungan usaha tetap berjalan sesuai dengan kebutuhan.
\end{abstract}

Kata kunci : Pendampingan, Pelaku Ekonomi Kreatif, Makanan Berbasis Singkong, Stimulan Dana, Covid-19.

\begin{abstract}
The purpose of education and mentoring (P2) is to monitor creative economic groups during the covid-19 outbreak. The target group for this service are creative economy actors (cassava), especially during the PSBB (2020 large-scale social restrictions) implementation period with methods carried out through continuous mentoring. The results of this dedication show that (i) the success of upstream activities, namely cassava farming which is being carried out continues as the condition before the Covid-19 outbreak, the stimulant impact of revolving funds does not feel burdensome (comfortable); (ii) the comfort that is built is indicated by an agreement (agreement) on the target group; and (iii) the return of 'revolving stimulant funds' is carried out through various variations according to ability. Recommendations that the program should continue and/or be developed because of the social impact in the form of comfort that appears when the program is running or running, the economic impact of sustainability (sustainable) business support continues according to need.
\end{abstract}

Keywords : Assistance, Creative Economy Actors, Cassava-based Food, Financial Stimulants, Covid-19.

\section{PENDAHULUAN}

Problem klasik pada petani yang ada di pedesaan adalah terjualnya tanah mereka pada petani 'berdasi' dan atau pada pengembang pada indutrsi perumahan. Hal ini merupakan tantang yang tidak ringan karena prestasi Indonesia sejak tahun 1984 menjadi negara berwasembada pangan hanya menjadi sejarah saja, untuk itulah jauh-jauh 
sebelumnya perlu dilakukan program aksi dalam rangka meminimisasi problem yang dihadapi dewasa ini.

Diestimasikan tahun-tahun berikutnya lahan pertanian akan semakin berkurang karena menurut Dinas Penanaman Modal Pelayanan Terpadu Satu Pintu (DPMPTSP) Kabupaten Malang, mengatakan bahwa 19 pemohon mengajukan permohonan izin serta difasilitasi terkait hal teknis lainnya. Sebagai refrensi, lahan sawah untuk alih fungsi lahan telah ada dan dibahas bersama para pemohon. Dimana, ada sekitar 24 hektar lahan kering warga di Jabung yang dimohonkan untuk jadi lahan basah. Lahan basah untuk sawah inilah yang nantinya direncanakan untuk mengganti lahan pertanian yang akan dialihfungsikan. Dari informasi proses untuk itu telah mencapai 80 persen. Dimana untuk pembiayaannya akan ditanggung oleh para pemohon, dengan anggaran untuk penggantian lahan pertanian itu mencapai Rp 600 juta.

Upaya yang dilakukan pemerintah kabupaten dalam mempertahankan ketahanan pangan dengan menambah usaha tani pangan khususnya padi, luas panen padi di Kabupaten Malang periode Januari-September 2018 sebesar 42.630 hektar. Dengan memperhitungkan potensi Oktober sampai Desember 2018, maka luas panen tahun 2018 adalah 52.579 hektar. Sehingga panen produksi padi di Kabupaten Malang pada periode Januari hingga Juli 2018 tercatat mengalami kenaikan sebesar 2,73 persen menjadi $328.257,54$ ton gabah kering giling (GKG), dari produksi tahun sebelumnya yang sebanyak $319.518,83$ ton. Pada 2018 dibanding 2017, produksinya meningkat. Peningkatan tersebut terjadi karena perluasan lahan tanam. Produksi gabah kering giling tersebut dikonversi menjadi beras, maka pada periode Januari-Agustus 2018 produksi Kabupaten Malang mencapai 219.932,54 ton beras. Angka tersebut naik dari periode yang sama pada 2017 yang sebesar 214.077,62 ton (Muhaimin, 2012).

Namun, peningkatan produksi padi untuk wilayah Kabupaten Malang tersebut tidak lepas dari kondisi curah hujan yang terbilang baik. Para petani yang berada di wilayah Kabupaten Malang sangat tergantung pada musim hujan, karena pada saat kemarau, sumber-sumber air juga mengering. Atas dasar itulah program pengabdian melalui stimulan dana ini sebagai salah satu program aksi yang merespon musim kemarau yang berkepajangan. Program ini dilakukan pada kelompok sasaran petani yang mempunyai lahan pertanian berupa tegal (lahan kering) untuk dilakukan usahatani singkong dalam pelaksanaan program ini. Kelompok sasaran dari hasil pendekatan dan pendampingan dilakukan usahatani singkong mulai dari hulu hingga hilir. Sebab dengan 'stimulan dana' sebagai 'insentif' agar mereka terdorong dengan melakukan aktivitasnya karena pada komoditas singkong dengan problematik di atas telah banyak ditinggal oleh petani, disamping komoditas ini tidak marketable dengan harga panen yang kurang menjanjikan (Novalianis, 2011; Askandar, Machfudz and Junaidi, 2017; Mansur, Machfudz and Widarko, 2017; Mansur, Machfudz and Kamilah, 2018; Abbas et al., 2019; Machfudz and Kamila, 2019; Machfudz, 2020; Mahfudz, 2020; Supriyanto et al., 2020).

Namum komoditas ini dekat dengan masyarakat tani, maka singkong menjadi pilihan komoditas subsitusi beras sebagai komoditas alternatif yang dapat dipakai sebagai andalan sekarang dan dimasa-masa yang akan datang. Karena singkong dapat dilakukan dengan deversifikasi produk untuk makanan siap saji, maka pendampingan dilakukan secara holistik dari hulu-hilir sampai pada pasar yang starter pintnya pada 'stimulan dana'. Atas dasar fenomena di atas, maka tujuan pengabdian ini adalah untuk melakukan pendampingan pada kelompok ekonomi kreatif makanan berbasis singkong pada aktivitas hulu hingga hilir, melalui kesepakatan bersama dari semua aspek (Masyhuri, 2015).

Sejak 20 tahun terakhir ini pendampingan dengan pndekatan 'partisipasi' cukup significant dipakai pada kalangan pengabdi dalam mengabdikan kepada masyarakat. Partisipasi merupakan pendekatan yang dilakukan dalam pemberdayaan pada berbagai macam variasi klas sosial, ekonomi dan budaya. Berbagai macam karakteristik lapisan masyarakat yang eksistennya cukup heterogen akan dapat mudah dalam mengadopsikan inovasi jika pendekatan empati yang partisipatori sehingga pada kelompok sasaran akan 
dengan mudah tujuan dapat dicapai. Tujuan utama pada entry pointnya adalah terjadi perubahan pada sikap, prilaku dan budaya yang lebih baik menguntungkan dari sosial ekonomi budaya tanpa merubah dan kondisi asli pada masyarakat, justru untuk melengkapinya.

Potensi dari pengalaman pribadi dan/atau pengalaman kelompok sebagai 'bahan baku' dalam melakukan proses pemberdayaan dalam menghasilkan karya (produk) baru yang menguntungkan dari segala aspek. Indikator keuntungan adalah berupa munculnya cipta, rasa dan karsa yang mendukung produk yang dihasilkannya guna mengoptimalkan potensi yang ada. Proses pemberdayaan selalu dikomunikasikan dan 'dikompromikan' agar tidak muncul konflik 'kepentingan’ baik secara individu maupun kelompok.

Proses partisipasi itu sendiri merupakan keterampilan yang pada dasarnya dimiliki oleh setiap personal, namun kemampuan ini perlu diolah dan dikomunikasikan untuk menciptakan proses partisipatif yaitu membangun kepercayaan diri, membangun proses dialog, memberikan pembelajaran dan keterampilan yang dapat diaplikasikan oleh peserta pelatihan dalam proses pendampingan. Didalam pelatihan ini, peserta pelatihan akan belajar bersama mengenai kemampuan dasar fasilitasi dan pendekatan partisipatif yang dapat diterapkan dalam proses pendampingan masyarakat sehingga para pendamping akan menjadi lebih baik dan lebih percaya diri. Peserta pelatihan akan memahami prinsip dasar dan teknik menggunakan metode partisipatif yang praktis dalam proses pendampingan masyarakat.

Target pada workshop pada proses pendampingan dan partisipatif, yaitu (i) pengantar fasilitasi dan pendampingan partisipatif; (ii) dasar-dasar komunikasi; (iii) metode pendampingan partisipatif; (iv) teknik pendampingan partisipatif dan (v) praktek atau demo fasilitasi. Harapan pada output pada aktivitas ini adalah (i) memperoleh pengetahuan dan keterampilan mengenai metode pendampingan partisipatif dan cara menerapkannya dalam pendampingan masyarakat dan (ii) memperoleh pengalaman menerapkan metode pendampingan partisipatif dalam pendampingan masyarakat.

Adapaun manfaat yang dapat diambil pada aktivitas ini adalah (i) berupa mengerti dan menyadari potensi dalam proses dan ruang lingkup pendampingan partisipatif; (ii) memperoleh referensi dan wawasan mengenai metode partisipatif dalam proses pendampingan; (iii) memperoleh pengalaman dalam simulasi pendampingan partisipatif dan (iv) peserta Pelatihan akan mendapatkan dukungan setelah pelatihan untuk membangun dan mengembangkan kemampuan mereka melakukan masyarakat yang partisipatif.

\section{METODE}

Metode, guna mencapai hal tersbut, maka dilakukan dengan metode mekanisme dalam pelaksanaan progranm dilakukan dengan partipatori yang bermanfaat untuk memfasilitasi dan memotivasi agar masyarakat mampu; (i) mengidentifikasi kekuatan dan kelemahan usahatani serta problematikanya; (ii) menemukenali faktor penyebab problem petani dan alternatif solusinya; (iii) menyusun strategi dan metode yang tepat untuk memecahkan usahatani singkong, dan olah hasil panen menjadi produk bahan baku 'antara' berupa gaplek dan chip yang dikordiner oleh start-up yang terbentuk atas kesepakatan (agreement) bersama.

Menyusun rencana aksi berdasarkan prioritas, dan keberlanjutan program melalui tahapan-tahapan hingga mencapai target yang diharapkan. Adapun strategi yang digunakan dalam melakukannya ini adalah menggunakan metode yang dikemukakan oleh O'Brien (2001) dengan ada empat tahapan dalam melakukan penelitian ini, yaitu perencanaan (plan) tindakan (action), pengamatan (observe) dan refleksi (reflect).

Usaha-usaha yang telah dilakukan dalam memecahkan problematika di masyarakat kelompok sasaran tersebut direfleksikan dan dievaluasi, baik kekurangan, kelemahan, dan 
keberhasilan strategi dan metode dalam memecahkan problematika mereka. Refleksi dan evaluasi ini berujung kepada perencanaan (plan) seperti pada poin pertama untuk menuntaskan problematika masyarakat, baik yang belum tuntas pada tahap pertama atau untuk memecahkan problematika yang baru hingga tercapai kelompok sasaran khususnya dan umumnya masyarakat tani.

Mekanisme pengabdian selanjutnya adalah, diskusi kelompok untuk sama-sama mengevaluasi pelaksanaan pendampingan khususnya berkaitan dengan ke-cocok-an dalam menjalankan pemberdayaan ini. Hal ini didasarkan pada pengalaman-pengalaman sejak program ini dijalankan tahun 2015. Baik yang dirasakan menguntungkan pada sosial dan ekonominya. Berdasarkan pada hasil diskusi ini keputusan selanjutnya adalah 'kesepakatan' dalam melakukan lanjutan program 'revisi-revisi' program demi kelangsungannya untuk kepentingan bersama-sama.

\section{HASIL DAN PEMBAHASAN}

Pendampingan yang dilakukan dengan pendekatan yang telah dicantumkan dalam metode pengabdian adalah di awali dari pendampingan pada aktivitas hulu, kelompok sasaran merasa nyaman dengan keputusan dalam usahatani singkong melalui pemanfaatan pematang lahan sawah. Kenyataan yang terjadi pada kelompok sasaran adalah kekurangan singkong - hal inilah mendorong untuk melakukan kesepakatan dalam usahatani singkong yang dapat mengatasi problem pada kebutuhan singkong semakin sulit yang dialami oleh pelaku ekonomi kreatif pada usaha makanan-makanan yang berbasis singkong.

Pendanpingan dalam pengabdian ini dilakukan rekayasa sosial sebagai upaya pemeberdayaan masyarakat melalui gerakan tanam singkong. Pelaku ekonomi kreatif melaksanakan bisnis perlu mendapat dukungan yang memadai, khususnya pada persediaan bahan baku berupa singkong. Hal ini dapat dilakukan melalui usahatani singkong dengan memanfaatkan potensi petani produsen.

Kenyamanan yang terbangun dalam melaksanakan usahatani singkong berbading lurus dengan kendala klasik yang mereka hadapi, yaitu dukungan dana usaha. Untuk itulah kendala ini dapat dilakukan dengan program pelatihan dan pendamingan yang didukung dengan 'insentif' berupa stimulan dana agar terjadi ikatan kuat sosialekonominya antar semua pihak yang terlibat dalam program.

Apabila pada program pendampinga sisi hulu ini tercapai, maka kekurangan singkong oleh pelaku ekonomi krratif makanan berbasis singkong akan teratasi, sebab dari hasil temuan Masyhuri dkk. Tahun 2007 yang menunjukkan bahwa semua kabupaten memproduksi singkong yang cukup melimpah menurtu BPS. Namun kenyataan di lokasi, bahan baku singkong masih sulit untuk diperoleh, bahkan terkesan langka untuk mendapatkannya. Disamping itu, permintaan singkong di Kabupaten Malang cukup tinggi yang diindikasikan dari informasi responden yang mengatakan kesulitan dalam mencari bahan baku pokok. Bahan baku pokok tersebut tersedia, namun mereka harus menempuh jarak yang cukup jauh untuk mendapatkannya. Salah satu distributor singkong mengakui adanya perebutan permintaan singkong antar pengusaha singkong gorengan dengan pengusaha tape singkong.

Pedagang tape singkong yang ditemukan di lapangan mengatakan bahwa sudah tiga hari tidak memproduksi tape karena kesulitan dalam mencari singkong. Juhari beserta istrinya sebagai pedagang gorengan yang cukup laris juga merasakan hal yang sama. Demikian juga ada yang dialami oleh beberapa pedagang singkong goreng, terlebih lagi dalam melakukan produksi mereka harus memakai singkong yang masih baru 
dipanen, jika sampai lebih dari satu hari, maka hasilnya akan menjadi kurang baik. Jadi kontinuitas pengadaan bahan baku adalah masalah yang cukup serius yang dihadapi oleh kelompok sasaran.

Kelompok sasaran mengakui bahwa pengaruhnya kontinuitas pengadaan bahan baku terhadap kemajuan usaha adalah cukup signifikan pada kelangsungan usaha. Teknologi produksi yang diaplikasikan adalah masih konvensional, tetapi dari beberapa kelompok sasaran produk yang dihasilkan tidak tidak terjual. Beda dengan yang dialami oleh penjual gorengan singkong. Hal yang menjadikan kenyataan ini terjadi adalah olah produk Juwari adalah dengan proses yang berbeda dengan kelompok sasaran lainnya.

Berdasarkan kendala bahan baku singkong yang sulit tersebut dan sekaligus dalam upaya pengembangan produk oleh kelompok sasaran, maka diversifikasi produk perlu untuk dilakukan. Divesifikasi merupakan upaya pengembangan usaha lain yang untuk mempertahankan keberlangsungan suatu bisnis. Dukungan bisnis ini akan bertahan apabila pasokan bahan bakunya dapat dipenuhi. Hasil penelitian ini menunjukkan bahwa rekayasa sosial yang dilakukan dengan melakukan intervensi pada aktivitas ekonomi masyarakat kelompok sasaran dalam menentukan pola usahatani dengan pengenalan lebih lanjut tanaman singkong dapat merangsang mereka dalam melakukan budidaya singkong sebagai komoditas sampingan disamping komoditas utama.

Sejak tahun 2009-2015 anggota kelompok sasaran telah melakukan usahatani singkong dengan rata-rata tingkat tambahan pendapata Rp.300.000-500.000,- mereka menyatakan bahwa tambahan pendapatan dari usahatani sampingan ini cukup puas. Indikator kepuasan dilihat dari jawaban kelompok sasaran 90\% menyatakan jawaban 4-5 pada skla linkert. Sebesar $10 \%$ menyatakan tidak puas karena kegagalan dalam panen karena hama tikus. Problem muncul adalah dalam pemanfaatan pematang lahan sawah karena tidak sesuai dengan morfologi dari tanaman singkong yang tidak membutuhkan kandungan air dalam tanah. Hasil pendampingan sejak tahun 2010-2016 kelompok sasaran tidak memanfaatkan pematang lahan sawah tetapi $100 \%$ pada lahan tegal dengan rata-rata produksi mencapai $1,5-2 \mathrm{~kg}$ per 10 meter pada pematang lahan sawah dan 4,5-5 kg per 10 meter pada pematang lahan tegal. Perubahan sosial atas kelompok program pendampingan ini melebihi $100 \%$, lebihnya $100 \%$ ini memberikan indikasi bahwa adanya program pendampingan memberikan dampak positif pada perubahan kelompok masyarakat yang diluar anggota program pendampingan.

Kausalitas perubahan ini adanya ungkapan dari anggota program pendampingan kepada masyarakat tanam singkong menjadikan 'lumayan' dalam penambahan pendapatan dan/atau tambahan makanan non beras yang dapat dipakaia sebagai makanan sampingan. Rasa simpati pada singkong ini menyebabkan mereka mencontoh untuk melakukan usahatani singkong sebagai tanaman sampingan dengan pemanfaatan pematang lahan tegal/sawah mereka. Bentuk perubahan sosial secara teori ada tiga bentuk, yaitu evolusi merupakan perubahan yang membutuhkan waktu, revolusi adalah perubahan yang sering diaplikasikan pada kenegaraan dan reformasi merupakan pola perubahan sintesa dari evolusi dan revolusi. program pendampingan adalah bentuk evoluasi yang bernuansa pada pola tanama dalam berusahatani yang dulunya tanaman singkong dilupakan, dengan program program pendampingan mereka mengadopsi yang orientasinya pada ketahanan pangan.

Strategi perubahan pada program program pendampingan adalah strategi persuasif (persuasive strategy) melalui media propaganda melalui metode FGD (focus group discussion) diskusi group yang terfokus pada agribisnis singkong pada keputusan didasarkan pada kesepakatan (agreement). Guna memberikan respon positif, maka dilakukan stimulan dana usahatani sesuai dengan kesepakatan kelompok. Tahun 2009- 
2015 stimulan dana Rp.200-300,- dan tahun 2016 sebesar Rp.500.00,- dengan pola pengembalian dalam bentuk singkong kering (gaplek).

Kepuasan pada kelompok binaan ini pada beberapa asek, yaitu kebebasan usaha, kebebasan usaha tani dan/atau makanan asal berbasis singkong. Kepuasan pada kebebasan dalam melaksanakan usaha atas dasar kesepakatan, hal ini memberikan tingkat kenyamanan pelaku, karena dengan pendampingan ini menjadikan sistem kelompok yang saling mendukung adanya pelaku ekonomi kreatif. Dukungan cukup memberikan tambahan ketenangan adalah terdapatnya dukungan permodalan dalam rangka kontinuitas usaha.

Pada aspek ini terdapat beberapa dalam pembentukan kelompok usaha, diantaranya adalah kesepakatan jumlah anggota, kesepakatan jumlah pinjaman, kesepakatan jumlah pengembalian, kesepakatan jumlah kelompok, kesepakatan jumlah waktu pengembalian (misalnya per pekan), kesepakatan jumlah tabungan berdasarkan laba yang diperoleh, kesepakatan jumlah penarikan tabungan, kesepakatan jumlah pinjaman untuk putaran berikutnya, kesepakatan jumlah mengisi uang suka rela (tanpa ditentukan) dengan misivisi: 'jangan isi iuran jika terpaksa, isilah iuran dengan senang hati'.

Solusi penyelesaian problem klasik yang dihadapi oleh para pelaku ekonomi kreatif, dimana solusi tersebut merupakan hasil kesepakatan antar peneliti dan kelompok sasaran. Solusi atas kesepakatan tersebut berupa pemberdayaan dana bergulir yang dirasakan sebagai kenyamanan dan mempunyai dampak langsung pada kelompok sasaran. Kelompok sasaran ini dalam melakukan usaha kreatifnya cukup banyak tetapi jumlah yang menjadi kelompok perubahan (the agent of change) guna membanguan jejaring sosial untuk memberdayakan usaha yang berkelanjutan ada 10 pelaku.

Program-program pemberdayaan yang dilakukan oleh pemerintah, perguruan tinggi maupn LSM dan lembaga lainnya tidak dapat menyentuh dan menjawab akar permasalahan pada kelompok sasaran dengan pendampingan dan pelatihan serta pembinaan secara kontinyu sehingga hasilnya tidak maksimal. Dalam pendampingan ini, maka optimalisasi dilakukan dengan penataan sistem manajemen yang baik dan proporsional dan sangat dibutuhkan bagi setiap usaha pelaku ekonomi kreatif (UKM).

Strategi ini menekankan pada upaya perubahan karakteristik produk yang berbasis pada inovasi dan kreatif dengan ciri yang khusus pembentukan brand di benak pelajar (konsumen). Diharapkan ke-unik-an ini mempunyai ciri-ciri khusus, yaitu adanya item tambahan yang dapat memperkuat atau menambah fungsi atau manfaat dari produk itu sendiri, inovasi dan kreatif pada terhadap produk yang dihasilkan, beradaptasi dengan sosial ekonomi pelanggan dan menyediakan sesuatu yang berharga dapat terus bertahan pada persaingan pasar dan jangka panjang.

'Kenyamanan' terbentuk juga pada pelaksanaan pendampingan pada pelaksanaan revolving fund, yaitu memberikan dorong motif pada usaha ekonomi kreatif, bukti mereka dalam melakukan pelaksanaannya $100 \%$ dana yang digulirkan tidak ada yang macet. Hal ini disebabkan karena tanggungjawab diangkat bareng-bareng berdasarkan pada semua anggota kelompok usaha. Hal yang menjadikan munculnya 'kenyaman' ini karena faktor tidak ada bunga, denda, semangat yang luar biasa karena mengedepankan kejujuran, tali persahabtan dan emosional terbangun secara positif.

\section{DAMPAK DAN MANFAAT}

Dampak utama program ini adalah munculnya 'kenyamanan' pada kelompok sasaran karena tidak merasa terbebani. Problem klasik berupa dana terpecahkan secara kebersamaan sehingga pengabdi dan mitra kondisi terbentuk sambal jalan bebarangan 
dengan pelaksanaan pendampingan pada pelaksanaan revolving fund, yaitu memberikan dorong motif pada usaha ekonomi kreatif, bukti mereka dalam melakukan pelaksanaannya $100 \%$ dana yang digulirkan tidak ada yang macet. Hal ini disebabkan karena tanggungjawab diangkat bareng-bareng berdasarkan pada semua anggota kelompok usaha. Hal yang menjadikan munculnya 'kenyaman' ini karena faktor tidak ada bunga, denda, semangat yang luar biasa karena mengedepankan kejujuran, tali persahabtan dan emosional terbangun secara positif.

\section{KESIMPULAN}

Berdasarkan pada pembahsan di muka, maka dapat disimpulkan bahwa (i) keberhasilan aktivitas hulu, yaitu usahatani singkong yang dilakukan oleh kelompok sasaran memberikan dampak pada 'roda' perekonomian rumah tangganya. Dampak ini terasa karena 'stimulan' dana atas dasar kesepakatan merasa tidak membebanninya sehingga dalam aktivitas usahataninya ada jaminan 'kenyamanan' seakan-akan tidak ada resiko pengembalian dana stimulan - pada benak pelakunya tidak ada traumatik pada kegagalan usahatani dan/atau kegagalan 'pasar'; (ii) 'kenyamanan' yang terbangun pada kelompok sasaran didorong atas bentuk pengembalian dana stimulan dalam bentuk beberapa pilihan sesuai dengan 'apa' yang bisa dilakukan (disepkati) oleh kelompok sasaran, yaitu berupa singkong, gaplek, tepung singkong, tepung mocaf dan tepung singkong yang dimodifikasi dengan tanaman-tanaman yang potensi kandungan nutrisi pangan, seperti junggala, kenikir, kemangi, kelor, dan lainnya; dan (iii) deskripsi pengembalian 'dana stimulan' dilakukan melalui berbagai macam variasi, kelebihannya pada program ini kenyamanan terbangun secara bagus dan harmonis, kelemahannya adalah pada kelompok sasaran (pelaku ekonomi) kadang lengah terhadap tanggungjawab secara ketat - bahkan terkesan 'meremehkannya', kendala-kendala yang muncul adalah ketidak tepatnya dalam pengembalian dana stimulan dilakukan oleh kelompok sasaran, dari sinilah saran yang dapat 'rekam' adalah perlu kedisiplinan dalam memenuhi kesepakatan yang diputusakannya.

Rekomendasi yang dapat disampaikan pada program ini adalah program tetap dilanjutkan dan/atau dikembangkan karena dampak sosialnya berupa 'kenyamanan' yang muncul saat/sedang/telah program berjalan dampak ekonomi keberlangsungan (sustainable) dukungan usaha tetap berjalan sesuai dengan kebutuhan.

\section{UCAPAN TERIMA KASIH}

Penyampaian ucapan terimakasih kepada pihak-pihak, (i) mitra kelompok sasaran ekonomi kreatif, (ii) paguyuban UMKM Kecamatan Karangploso Kabupaten Malang, (iii) Universitas Islam Malang (UNISMA) atas dukungan dana pengabdian melalui program Hibah Institusi UNISMA (HI-MA) dan pengelola Jurnal Aplikasi Dan Inovasi Ipteks SOLIDITAS Universitas Widya Gama Malang.

\section{REFERENSI}

Abbas, M. H. I. et al. (2019) 'Pemberdayaan Santri Pondok Pesantren Anwarul Huda Di Bidang Ekonomi Kreatif', in. Seminar Nasional Pengabdian kepada Masyarakat, pp. 753-759.

Askandar, N. S., Machfudz, M. and Junaidi, J. (2017) 'The Implementation of Innovative Corporate Social Responsibility (CSR) Model in Indonesia', IJTS (International Journal Of Technology And Sciences), 1(2), pp. 6-9.

Machfudz, M. (2020) 'Optimization of Cassava-Based Non Rice Food Development Using Funds Stimulation of Qardhul-Hasan Transactions', MEC-J (Management

\begin{tabular}{ll|l}
\hline \hline SOLID & Machfudz, Kontinyuitas Pendampingan Pelaku Ekonomi ... & 67
\end{tabular}


and Economics Journal), 4(1), pp. 59-72.

Machfudz, M. and Kamila, N. (2019) 'Empowerment of Small Businesses through The Implementation of Qardhul Hasan Financing', Journal of Socioeconomics and Development, 2(2), pp. 99-106.

Mahfudz, M. (2020) 'Responsi Masyarakat Dampingan Pada Inovasi Program Rumah Pangan Lestari Melalui KKN-PPM Unisma Malang', Jurnal Aplikasi Dan Inovasi Ipteks SOLIDITAS, 3(1), pp. 1-5.

Mansur, M., Machfudz, M. and Kamilah, N. (2018) 'Inovasi Model Pinjaman Dana Bergulir Sebagai Stimulan Melalui Transaksi Qordhu-Hasan Pada UMKM', in. Prosiding Seminar Nasional Islam Moderat, pp. 103-109.

Mansur, M., Machfudz, M. and Widarko, A. (2017) 'Revitalization of SMEs'creative Businesses in Indonesia to Face Asean Economic Free Trade', IJEM (International Journal Of Engineering And Management), 1(2), pp. 33-39.

Masyhuri, M. (2015) 'Optimalization Of Cassava Distribution And Marginal Area Usage For Supporting Food Endurance', International journal of Applied Engineering Research Editor-in-Chief. Prof. Ir. Dr. Mohd Sapuan Salit. RIP Reseacrh India Publications http://www. Ripublication. com, 10(1).

Muhaimin, A. W. (2012) 'Analisis efisiensi teknis faktor produksi padi (oryza sativa) organik di desa sumber pasir, kecamatan pakis, kabupaten malang', Agricultural Socio-Economics Journal, 12(3), p. 193.

Novalianis, R. S. G. (2011) 'Pengaruh Pinjaman Dana Bergulir dan Pendampingan Terhadap Kegiatan Usaha Ekonomi Produktif Pada Program Nasional Pemberdayaan Masyarakat (PNPM) Mandiri di Kecamatan Karanggede Kabupaten Boyolali', Skripsi, Universitas Negeri Semarang.

Supriyanto, A. S. et al. (2020) 'The use of information technology as a mediator on the effect of transformational leadership and creativity towards student achievement', Talent Development and Excellence, 12(1), pp. 1765-1775. 